\title{
Art in the Age of Digital Reproduction: Reconsidering Benjamin's Aura in "Art of Banksy"
}

\author{
Canan Akın and N. Sezin Kıpçak \\ Istanbul YeniYuzyil University Radio and Television Programming Department, Turkey
}

\begin{abstract}
Since Walter Benjamin wrote his renowned essay "The Work of Art in the Age of Mechanical Reproduction" in 1936, the aura of an artwork has always been an issue of debate. Benjamin describes aura as "an art work's unique existence at the place it happens to be" and claims that the aura of an art work is born out of the combination of factors such as uniqueness, tradition, distance and authenticity. Benjamin announces the "death of aura" as a consequence of new technologies which enable artworks to be reproduced mechanically. Benjamin's claim is primarily true in works of art in digital form, including graffiti art reflected on screens via digital technologies. Graffiti art, which reacts against the commodification of all things including time and space, is commodified when it is displayed in an environment which is different from the one its meaning was rooted and thus is deprived of its aura. This paper aims to discuss how Benjamin's "aura" finds its reflections in Graffiti art. It proposes that commodification of "graffiti" artworks and displaying them in new sites via digital technologies leads to vanishing of their aura. In the light of Benjamin's views, the exhibition titled "The Art of Banksy", which had its world premiere in Istanbul in January 2016 will be examined on its capacity to evoke aura.
\end{abstract}

Key words: Aura, Benjamin, Banksy, graffiti.

"Even the most perfect reproduction of a work of art is lacking in one element: its presence in time and space, its unique existence at the place where it happens to be"

WalterBenjamin

\section{Introduction}

Although it has been 80 years since Walter Benjamin wrote his famousessay "The Work of Art In the age of Mechanical Reproduction", his concept of "aura" is still an issue of discussion in our present days. Living in an age artworks were reproduced mechanically by means of photographs or films, Benjamin claimed that the new technologies which enable artworks to be reproduced mechanically led to the death of their aura. Describing aura as, "an artwork's unique existence at the place it happens to be" (Benjamin, 2007: 20) Benjamin assert sthataura of an artwork is specific to the context in which it is createdanddisplayed. Benjamin's conception of theaura of an artwork is theresult of the synthesis of

Corresponding author: Canan Akin, assistant professor, research field: new media and art. its uniqueness, tradition, distance and authenticity.

Today, we are witnessing the digital era and Benjamin's claim about the aura of an artwork is primarly true in works of art in digital form, including graffiti art reflected on screens via digital technologies. One of the key features of graffiti is its being site specific, which means a particular visual communicates a meaning in time and space. Another unique key feature of graffiti is its reacting against the commodification of all things, including time and space. However, when graffiti is exhibited in galleries and museums, it becomes a commodity and loses its aura even as it tries to exist as anti-commodity. In Benjamin'sview, despite leading to the death of aura, mechanical reproduction has some positive aspects such as enabling large masses of audiences to have an access to artworks which are in distant places. More people have the chance to experience the reproduced 
artworks which are displayed in their accomodation areas, but still these artworks lack aura due to being in a place other than the place of their creation.

The aim of this paper is to search for Benjamin's "aura" in graffiti art. The paper claims that when graffiti is moved into galleries and museums by means of digital reproduction, its aura withers. Commodification and displaying graffiti in an environment which is different from the one its meaning was rooted are the prevailing reasons for the vanishing of graffiti's aura. Starting with a brief definition of Graffiti art and how these features correlate to the aura og graffiti art. In the final part of the paper, in the light of Benjamin's views, the exhibitiontitled, "The Art Of Banksy" which had its world premiere in Istanbul in January 2016 will be examined on its capacity to evoke aura.

\section{Graffiti Art}

Literal translation of the word graffiti is "little scracthings", from the Italian verb graffiare, meaning to "scratch". Some of the earliest examples were the mélange of political commentary, real estate advertisements, lost and found notices and quotations from Virgil and Ovid scratched into the walls of Pompeii. Mediavel graffiti often comprised inscriptions incised into churches. Like its medieval antecedents, contemporary graffiti attempts to communicate a message. These messages generally fall into broad categories-social or political commentary, or personal communications [1] .

Graffiti is the art form of a complex urban subculture. A subculture can be defined as a distinctive social group within a larger social group that creates its own cultural patterns. In the urban environment, graffiti artists have made their artwork part of an intricate subculture that not only embraces aerosol art as an art form, but also stickering, found object art, public art, forms of performance art [2].

Street art and graffiti became widespread between the years of 1960 and 1970, especially in New York.
Artists started to tag their nicknames to the walls, subways and automobiles. As a form of visual arts, graffiti uses the public space as an alternative communication tool. This tool makes social and political issues visible and let realities of life flow to the city.

\subsection{Benjamin's Aura in Graffiti Art}

People have been drawing on walls since the Stone Age but modern Graffiti art can be traced to the late 1960 's in the United States. Graffiti, as we know it today, can be described as "writing or drawings scribbed, scratched or sprayed illicitly on a wall or other surface in a public place". Graffiti has been considered as an anti capitalist movement which provides subcultures and minorities with a platform to express their ideas and identity. In other words, being an illegitimate art form with political meanings, graffiti was not considered as a mainstream art. As several graffitists, such as Keith Haun Basqual and Banksy became known worldwide graffiti, began to enter the world and market of art [3].

The most important characteristic of graffiti art is its being site specific. The street is the canvas for graffiti. It gets its power from the right choice of location. Unlike any other form of art, graffiti depends on their contextual environment. In other words, graffiti uses the material existence of the place or city in which they are created [4].

Graffiti art gains its aura mainly from being in a place it is not allowed to be and it is present only as long as the authorities allow. This means, for graffiti ephemerality is a built-in characteristic. To make his point clear, it is possible to have a look into some works of the well-known graffiti artist, Banksy. The aura of Banksy's works relies on the temporality of street art. His works target the sites relevant to the political issue the piece aims to highlight: for example, Banksy's painting of a tropical beach on the Israel-Palestine Wall is in a way questioning the legitimacy of the wall itself and is making a political 
statement. In Banksy's own words: "Palestine is now the world's largest open-air prison surrounded by a wall which is three times the height of the Berlin Wall. On the other hand, it is the ultimate activity holiday destination for Graffiti artists". Banksy's drawing of a ladder along the height of the Israeli Wall is also outstanding. The political issue he wants to highlight here is the powerlessness of Palestinian people to overcome the wall. $\mathrm{He}$ is also questioning the authority of the wall and the state who built it. If Banksy's paintings of the "tropical beach" and the "ladder" would be carried to another location or to a gallery or museum by means of mechanical or digital reproduction, their effect, their meaning, their aura would be lost. Again this reminds us of Benjamin's concept of aura. For Benjamin aura is captured only within the original and the authentic; it is specific to the context in which it is created and displayed [5-6].

"...In the case of the art object, a most sensitive nucleus - namely, its authenticity - is interfered with whereas no natural object is vulnerable on that score. The authenticity of a thing is the essence of all that is transmissible from its beginning, ranging from its substantive duration to its testimony to the history which it has experienced. Since the historical testimony rests on the authenticity, the former, too, is jeopardized by reproduction when substantive duration ceases to matter. And what is really jeopardized when the historical testimony is affected is the authority of the object [7]."

Similarly, Banksy's works get their authority specifically from his targeting of sites relevant to the political issue the piece aims to highlight. The aura of his work relies on the temporality of graffiti. The time in which it is viewed by the observer reflects "the history to which it was subject throughout the time of its existence [7]".

The fluidity and contextual relevance of graffiti art means that it is difficult to invoke the political reaction the artist aims to create through the reproduced image which is carried away from its place of creation. Benjamin argues, the removal of aura leads to a loss of authority not only in the artwork but in the audience as well. As a result, when reproduced mechanically graffiti art is depoliticized because it is alienated from the context from which it was rooted [8].

Another important feature of graffiti art is its being against capitalism, commodification and consumption. However, in the 1970's commercial world started to use graffiti in their marketing campaigns. This led to commodification of graffiti art and as a result there was an increase in its market value. It became a legitimate art form and moved into galleries from the streets. Commodified and exhibited in galleries and museums, graffiti art becomes a commodity even though it tries to exist as anti-commodity. This commodification influences the politic dynamics of this art form. In other words, commodification leads to its becoming depoliticized and thus vanishing of its power and aura [8].

When graffiti is transferred from the walls to a canvas, page or screen, it stops being graffiti and becomes mainstream art. Likewise, when Banksy prints his stencils in a book or exhibits his works in exhibitions, he is converted into a conventional artist.

As we have mentioned earlier in the text, graffiti art gains its aura from the place of its creation, which is usually a place it is not allowed to be. Banksy claims that, when his art moves from the streets to an art gallery, his work ceases to be "the most honest art form available" because people can now be "put off by the price of admission". In other words it becomes a commodity which can be analysed, criticized and packaged and this absolutely leads to the vanishing of its aura. According to Banksy, Graffiti art has the level of honesty that commercial art can never achieve:

"Graffiti is not the lowest form of art. Despite having to creep about at night and lie your mum, it's actually the most honest art form available. There is no elitism or hype, it exhibits on some of the best walls 
a town has to offer, and nobody is put off by the price of admission [5]".

Another point that Benjamin puts forward about the aura of an artwork is the sense of distance created between the art object and the spectator. He defines aura as, "the unique phenomenon of a distance however close it may be [7]'. He claims that bringing things "closer" spatially and humanly by means of reproduction overcomes the uniqueness of every reality. What Benjamin means by distance here is the reverence that the spectator feels in front of an original object. He feels as if the piece of art is unreachable although it is at a reachable distance.

Benjamin's claim is also valid for graffiti art. When graffiti are displayed in their places of creation, they arouse a feeling of awe and respect. Their message is delivered in a strong manner. However, when it is reproduced and displayed in galleries this distance is eradicated and the aura is lost.

Today, intersection of graffiti art and popular culture is taking place in the marketplace, where these forms are transformed into coveted merchandise. At one end of the spectrum is the sale of original graffiti art pieces as artworks. The winning bid at a 2007 Sotheby's auction for and acrylic and spray paint stencil on canvas by the Banksy was 200,000 dollar, that same year another of his paintings fetched a record 575,000 at a Bonham's sale. This also shows us that graffiti art, specially Banksy's artwork lose its authenticity and protest atmosphere in today's capitalist marketplace [1].

As can be seen from the above discussion, Benjamin's views on the "death of aura" of an artwork are viable for graffiti art. In the next section, in the light of the Benjamin's views, "The Art of Banksy" exhibition will be analyzed on its capacity to evoke aura.

\section{The Art of Banksy}

Banksy is probably the most famous graffiti artist whose real identity is unknown. Some people consider him as "guerilla" street artist whereas others consider him as an artistic genius. His artwork is characterized by striking images, often combined with slogans. His work often engages political themes, satirically criticizing war, capitalism, commodification hypocrisy and greed [9].

"The Art of Banksy" exhibition, which brought together the famous works of the mysterious graffiti artist Banksy, made its world premiere in Istanbul on January 13 at "Global Karakoy". Curated by Steve Lazarides and organized by Istanbul Entertainment Group, the exhibition exposed Banksy's works made over the last 15 years. The exhibition showcased a special Banksy collection owned by Lazardes and brought together Banksy's most famous pieces by using the latest technology. The value of the collection was announced to be 20 million pounds.

"The Art of Banksy" exhibition is a powerful example to clarify that being reproduced, graffiti art loses its sprit and aura. Several points contradicting with the philosophy of graffiti art have been observed while making an analyses of the exhibition [10].

First of all, visitors had to pay an entrance fee of 35 Turkish Liras in order to enter the exhibition. This is a clear sign of commodification and contradicts with philosophy of graffiti art. Banksy had stated that "graffiti was the purest art form" because whoever wanted to see it or draw it was welcome to do so. However, by taking graffiti off the walls into an art gallery, its pureness was lost-because only the people who could afford could go into the gallery to see the graffiti works. In other words, being commodified, graffiti works in the exhibition were stripped off their political meaning and aura.

Another point is that, Banksy's works from all over the world were taken away from the places where their meanings were rooted and placed on the walls inside the exhibition building. Although the curator tried to create an artificial environment similar to London streets, this was also a kind of reproduction and was not enough to create the auratic experience. 
The art works were stripped off their aura because in Benjamin's words, "aura is specific to the context in which it is created and displayed." In other words, they were not displayed in their contextual environment and therefore their aura had withered.

"The Art of Banksy" exhibition aimed to bring Banksy's Graffiti works close to Turkish people who would not have the chance to see them in another way. In addition, the exhibition aimed to promote Banksy in Turkey. It is a fact that over 20,000 people visited the exhibition which would be impossible if the exhibition had not been held. However, as Benjamin stated, "aura is the unique phenomenon of distance however close it may be". The exhibition brought Banksy's works closer but the distance, the awe, the aura of the works were eradicated as well.

During the period of the exhibition, there was a great deal of discussion going on in the art world about how Banksy would allow such an exhibition which was completely contradictory to his philosophy. Criticizing capitalism, commodification and consumerism in his works, Banksy had in a way become part of the system he had criticized. The exhibition also included a simulation of Banksy's film "Exit through the Gift Shop" which he made in 2010. In "Exit through the Gift Shop", Banksy shows how the aura of art and artist becomes exploited for monetary gain.

When you finished your tour around the exhibition, you literally had to exit through the gift shop in which some souveniers with Banksy's works on were sold. This was also an illustration of Banksy's art being commercialized and commodified [11].

\section{Conclusions}

The effects of vast technological changes can be witnessed in all kinds of art, including street art or graffiti. Graffiti art, which uses the walls as canvas, gets its power from the right choice of location. When graffiti is taken off the walls into galleries, its aura withers and it loses its political meaning. In addition, when graffiti is reproduced and exhibited in galleries, it is no longer graffiti but mainstream art. Although it is an art which reacts against capitalism and commodification, it is commodified and becomes part of the capitalist system when it is displayed in galleries. This leads to the deprivation of its aura.

"The Art of Banksy" exhibition held in Istanbul brought together Banksy's most famous works and presented them to Turkish people. Although a natural London atmosphere was tried to be created, the exhibition was more like a traditional art exhibition rather than graffiti. For graffiti, to be exhibited in a gallery, almost all the works had to be reproduced by means of different kinds of media. Although these reproductions enabled many people to see Banksy's works, they lacked the most important feature an artwork must have: the aura. In short, Banksy's works in "The Art of Banksy" exhibition were not graffiti anymore. They were more like traditional art exhibited in a gallery, deprived of their political meaning and aura.

\section{References}

[1] Gottlieb, L. 2008. Graffiti Art Styles: A Classification System and Theoretical Analysis. USA: McFarland \& Company, Inc., Publishers.

[2] Farris, L. 2009. "Challenging Conceptions: The Fine Art of Graffiti.” Master of Arts. Kansas City, MO.

[3] www.oxforddictionaries.com.

[4] Pan, L. 2015. "Aestheticizing Public Space: Street Visual Politics in East Asian Cities." Intellect Books, UK.

[5] Banksy, W., and Piece. 2005. Wall and Piece. Century, London.

[6] Raychaudhuri, A. 2013. "Just as Good Place to Publish: Banksy, Graffiti and the Textualisation of the Wall." Journal on Interdisciplanery Studies in Humanities 2 (1): 54.

[7] Benjamin, W. 2007. "The Work of Art in the Age of itsTechnological Reproduction.” SimonDuring, Cultural Studies Reader, Routledge, London.

[8] Beecham, N. 2013. "Transforming the Aura: An Analysis of The Political Nature of Walter Benjamin's Aura in the work of Street Artists." Cultural Theory and Cultural Forms LSE Module SO 434: 2-3.

[9] The Art of Banksy, Exhibition Book, Istanbul Entertainment Group. 
[10] Hurriyet Daily News. 2016. "The Art Of Banksy Makes World Premiere in Istanbul." http://www.hurriyetdailynews.com/the-art-of-banksy-ma kes-world-premiere-in-istanbul.aspx?pageID $=238 \&$ nid $=9$
3859ErişimTarihi: 3 Nisan 2016.

[11] Daily, Wyatt. 2012. Exit through the Gift Shop. Emergence: A Journal of Undergraduate Literacy Criticism and Creative Research. 